\title{
Visualisasi Data Menggunakan Sistem Informasi Geografis untuk Potensi Bank Sampah di Surabaya
}

\author{
Muhammad Zaky Erdiansyah ${ }^{1)}$, Taufik ${ }^{2)}$, Indra Kharisma Raharjana ${ }^{3)}$ \\ ${ }^{1,2,3)}$ Program Studi Sistem Informasi, Fakultas Sains dan Teknologi, Universitas Airlangga \\ Kampus C Unair Mulyorejo, Surabaya \\ ${ }^{1)}$ muhammad-z-e-11@fst.unair.ac.id \\ 2) taufik@fst.unair.ac.id \\ ${ }^{3)}$ indra.kharisma@fst.unair.ac.id
}

\begin{abstract}
Abstrak-Bank sampah adalah tempat pemilahan dan pengumpulan sampah yang dapat didaur ulang dan digunakan ulang yang memiliki nilai ekonomi. Bank sampah memiliki potensi sampah yang bermanfaat, terdiri dari potensi sampah plastik, kertas, kaca dan besi. Potensi sampah tersebut dibutuhkan oleh perusahaan yang menggunakan bahan baku dari barang bekas pakai untuk di daur ulang menjadi produk yang memiliki harga di pasaran. Permasalahan bank sampah di Surabaya dapat dibagi menjadi dua masalah utama, yaitu pemantauan kegiatan bank sampah dan pencarian letak bank sampah beserta potensi yang dimiliki. Kedua permasalahan tersebut dapat diselesaikan dengan visualisasi data menggunakan sistem informasi geografis untuk potensi bank sampah di Surabaya. Sistem ini dibangun dengan langkah langkah sebagai berikut, yaitu pertama melakukan pengumpulan kebutuhan, analisis kebutuhan, perancangan sistem, pembangunan prototype, evaluasi dengan pengguna, pengembangan skala besar dan evaluasi sistem. Hasil evaluasi sistem menunjukkan bahwa $100 \%$ sistem berjalan dengan baik dan benar, $\mathbf{4 2 . 3 \%}$ user sangat setuju, $51 \%$ user setuju, $6 \%$ user tidak setuju, dan $0.7 \%$ user sangat tidak setuju bahwa visualisasi data menggunakan sistem informasi geografis untuk potensi bank sampah di Surabaya mempermudah pemantauan kegiatan penimbangan bank sampah dan mempermudah pencarian letak bank sampah beserta potensi yang dimiliki.
\end{abstract}

Kata Kunci-bank sampah, visualisasi data, Sistem Informasi Geografis.

Abstract-Trash bank was the place for sorting and collecting garbage that could be recycled and reused and had economic value. Trash bank had potential benefits, such as potential plastic, paper, glass and iron waste. This potential waste was needed by companies that use raw materials from used goods to be recycled into products that had market potential. Problems of trash bank in Surabaya could be divided into two main issues, first was the monitoring of the trash bank's activities, second was the search of trash bank location and its potential. Both of these problems could be solved by the data visualization using geographical information system for potential trash bank in Surabaya. This system was built with the following steps: requirements collection, requirements analysis, system design, prototype development, user evaluation, development of large-scale systems and evaluation. Results of the evaluation of the system showed that $100 \%$ of the system ran properly, $42.3 \%$ of users strongly agree, $51 \%$ of users agree, $6 \%$ of users did not agree, and $0.7 \%$ of users strongly did not agree that visualization of data using geographic information system for potential trash bank in Surabaya succeeded to facilitate the monitoring process of the of trash weighing activities in trash banks and helped the search of trash bank with its potential much easier.

Keywords-Trash Bank, Data Visualization, Geographical Information System

Article history:

Received 11 December 2015; Received in revised form 12 January 2016 \& 22 April 2016; Accepted 26 April 2016; Available online 30 April 2016

\section{PENDAHULUAN}

Kota Surabaya merupakan kota besar yang mempunyai permasalahan kompleks, khususnya sampah. Menurut website Badan Pusat Statistik (Surabaya, 2014), jumlah penduduk di Surabaya tahun 2014 telah mencapai 2.821 .929 rumah tangga. Sedangkan, Kementerian Lingkungan Hidup mencatat pada 2012 rata-rata penduduk Indonesia menghasilkan dua kilogram sampah per orang perharinya (Utami, 2013). Artinya, terdapat lebih dari 5.000 ton sampah perharinya yang dibuang oleh penduduk asli Surabaya.

Data Dinas Kebersihan dan Pertamanan tahun 2013 menyebutkan bahwa sebanyak 125 komunitas Rukun Warga (RW) di seluruh Kota
Surabaya telah berpartisipasi aktif dalam program Bank Sampah (Maziya, 2014).

Menurut Peraturan Menteri Lingkungan Hidup Republik Indonesia nomor 13 tahun 2012 tentang pedoman pelaksanaan reduce, reuse, dan recycle melalui bank sampah pasal 1 ayat 2 menjelaskan bahwa bank sampah adalah tempat pemilahan dan pengumpulan sampah yang dapat didaur ulang dan digunakan ulang yang memiliki nilai ekonomi.

Bank sampah memiliki potensi sampah yang bermanfaat, terdiri dari potensi sampah plastik, kertas, kaca dan besi. Potensi sampah kertas terdiri dari kertas, koran, kertas dupleks dan kardus. Potesi sampah plastik terdiri dari gelas plastik, plastik non botol dan botol plastik. Potensi 
sampah tersebut dibutuhkan oleh perusahaan yang menggunakan bahan baku dari barang bekas pakai untuk di daur ulang menjadi produk yang memiliki harga di pasaran.

Di Surabaya terdapat lebih dari 125 bank sampah yang dikelola oleh berbagai pengelola. Jumlah tersebut akan selalu bertambah dari tahun ke tahun. Sebagai pengelola yang menaungi bank sampah dengan jumlah besar, mereka memiliki masalah dalam pemantauan kegiatan penimbangan untuk membedakan bank sampah aktif dan tidak aktif. Dari pemantauan tersebut bisa didapatkan informasi bank sampah mana saja yang tidak melakukan penimbangan bulanan. Hal ini bertujuan untuk membantu pengelola menentukan tempat sosialisasi ulang di bank sampah yang tidak aktif melakukan penimbangan.

Bank sampah harus memberikan laporan penimbangan setiap bulan. Bank sampah membuat laporan secara manual tidak tercatat dalam sistem. Laporan dapat diambil oleh petugas We Hasta setiap bulannya. Laporan bentuk manual memungkinkan data hilang atau rusak sehingga data penimbangan tidak tercatat.

Perusahaan dan pengepul juga mengalami kesulitan mendapatkan sampah yang diinginkan. Saat ini, perusahaan mendatangi pengepul untuk mencari bahan baku dari potensi bank sampah. Maka dari itu bank sampah menjual potensi sampahnya kepada pengepul. Potensi dari bank sampah juga bermanfaat bagi rumah tangga sekitar bank sampah yang menjadi nasabah. Nasabah dari bank sampah dapat memiliki tabungan dari sampah yang mereka setor ke bank sampah, tabungan ini dapat diambil sewaktuwaktu.

Pengepul seringkali kesulitan mendapatkan sampah daur ulang untuk memenuhi kebutuhan perusahaan langganan. Pengepul saat ini hanya menunggu panggilan dari satu bank sampah dan sulit untuk menemukan bank sampah lain yang menyediakan bahan baku yang diperlukan pengepul. Pengepul membutuhkan suatu visualisasi data titik letak bank sampah beserta potensi terakhir yang dimilikinya, dengan begitu pengepul mudah mencari bahan baku yang dibutuhkan oleh perusahaan langganan mereka.

Ruang lingkup penelitian terdahulu menggunakan satu bank sampah dan data penimbangan yang diperoleh disimpan di database lokal. Namun, belum menggunakan data lokasi bank sampah dan data penimbangan sampah sebagai data pendukung untuk informasi yang akan ditampilkan. (Fitria, 2015) membahas pembuatan sistem informasi yang berfungsi mengelola data transaksi di sebuah bank sampah yang menggunakan metode waterfall dalam pengembangan sistem. Penelitian yang dilakukan Fitria menghasilkan sebuah perangkat lunak yang berfungsi mengelola data penimbangan sampah di satu bank sampah. (Noviandi, Destiani, \& Partono, 2012) melakukan penelitian yang bertujuan untuk mempermudah dan mempercepat pekerjaan kasir dalam mengakomodasi transaksi tabungan dan laporan tabungan di bank sampah Garut. Hasil peneitian dari Noviandi adalah sebuah perangkat lunak yang memiliki fungsi sebagai sistem kasir transaksi tabungan dari bank sampah. Berdasarkan dua penelitian tersebut maka akan dilakukan pengembangan dari kedua hasil penelitian tersebut. Hasil yang ditawarkan adalah mengelola transaksi beberapa bank sampah dalam satu wilayah operasi dan menampilkan data olahan transaksi tersebut ke dalam sistem informasi geografis.

Berdasarkan permasalahan yang telah diuraikan maka diusulkan solusi dengan cara visualisasi data menggunakan sistem informasi geografis untuk potensi bank sampah di Surabaya.Eksplorasi set data yang besar merupakan masalah penting tetapi cukup rumit. Teknik visualisasi informasi dapat membantu untuk memecahkan masalah tersebut (Keim, 2002). Visualisasi data menggunakan sistem informasi geografis dilakukan dengan dua metode dalam representasi data, yaitu gradasi warna yang berbeda dan grafik overlay. Gradasi warna yang berbeda untuk menampilkan distribusi wilayah. Grafik overlay untuk menampilkan proporsi variable yang menjadi indicator (Reveiu \& Dardala, 2011).Penggunaan Google Maps API V3 menyediakan mekanisme yang sangat efisien untuk menyampaikan informasi kartografi digital bagi pengguna internet dengan waktu respon yang cepat dan interaksi user yang mudah dimengerti (Hai \& Dai, 2013).

Data bank sampah beserta potensinya diperoleh dari LSM We Hasta yang berperan sebagai klien. Dengan adanya penelitian ini diharapkan dapat mempermudah stakeholder dalam melihat persebaran bank sampah. mengelola data bank sampah, dan pelaporan penimbangan setiap bulannya.

\section{METODE PENELITIAN}

\section{A. Pengumpulan kebutuhan}

Identifikasi kebutuhan dilakukan untuk mendapatkan data dan informasi terkait kegiatan proses bisnis pemantauan bank sampah. Teknik yang digunakan dalam identifikasi kebutuhan dalam penelitian ini adalah sebagai berikut:

1) Wawancara: Melakukan wawancara dengan pengguna sistem dalam hal ini adalahPenganggung jawab proyek visualisasi data dari LSM We Hasta, Pengepul dan Pengelola bank sampah 
2) Observasi: Melakukan observasi secara langsung terhadap dokumen yang berkaitan dengan prosedur-prosedur dalam proses bisnis bank sampah, pelaporan dari bank sampah ke We Hasta dan data apa saja yang harus ditampilkan dalam sistem visualisasi data.

\section{B. AnalisisKebutuhan}

Data yang telah terkumpul selanjutnya dianalisa dan kemudian merumuskan solusi untukmemecahkan permasalahan yang ada. Dalam tahap ini hal-hal yang perlu dianalisis adalah hambatan yang dialami, pengguna sistem, dan fungsi yang ditangani sistem.

\section{Perancangan sistem}

Pada tahapan perancangan sistem digambarkan dalam bentuk diagram-diagram UML antara lain: usecase diagram, activity diagram, class diagram, sequence diagram, dan ER diagram. Diagram tersebut digunakan sebagai acuan dalam pembangunan sistem.

\section{Pembangunan prototype}

Pada tahapan pembangunan prototype hasil dari perancangan diimplementasikan dengan pengkodean program menggunakan dua bahasa pemrograman yang berbeda, aplikasi bank sampah dengan platformoffline akan menggunakan JAVA sedangkan sistem aplikasi server dan visualisasi data akan menggunakan PHP, kedua aplikasi tersebut akan menggunakan DBMS yang sama yaitu MySQL. Hasil dari tahapan pembangunan sistem adalah sebuah aplikasi yang dapat dijalankan.

\section{E. Evaluasi dengan pengguna}

Pada tahapan evaluasi dengan pengguna adalah diskusi atas protoype yang telah dikerjakan. Klien akan mencoba prototype dan meberikan masukan fitur yang harus diperbaiki dari prototype tersebut. Tahapan ini dilakukan sampai klien merasa prototype telah memenuhi kebutuhannya.

\section{F. Pengembangan skala besar}

Tahapan pengembangan skala besar dilakukan setelah prototype telah memenuhi kebutuhan klien. Pada tahapan pengembangan skala besar yang dilakukan adalah penerapan sistem pada lingkungan. Sistem offline dalam bentuk file executable dan sistem online dapat diakses melalui browser di komputer atau smartphone pengguna.

\section{G. Evaluasi sistem}

Tahapan terakhir dalam penelitian ini adalah evaluasi sistem visualisasi data yang sudah dibangun dengan cara membandingkan antara pencarian dengan menggunakan sistem visualisasi data yang baru dengan pencarian secara manual yang selama ini digunakan. Perbandingan didapatkan dari timbal balik atau feedback hasil simulasi oleh pengguna dalam hal ini adalah LSM We Hasta, pengelola bank sampah, dan End user. Simulasi dilakukan berdasarkan skenario pengujian yang telah dibuat. Kuesioner digunakan untuk mengetahui bagaimana respon pengguna setelah melakukan simulasi. Evaluasi dilakukan untuk menilai apakah sistem visualisasi data yang baru dapat menyelesaikan permasalahan yang muncul pada sistem pencarian secara manual yang selama ini digunakan.

\section{HASIL DAN PEMBAHASAN}

\section{A. Pengumpulan kebutuhan}

a) Observasi

Observasi berkas berupa informasi yang terkait dengan proses bisnis bank sampah dan LSM We Hasta, diantaranya adalah : format laporan bulanan bank sampa ke We Hasta dan format rekapitulasi bulanan bank sampah yang dimiliki We Hasta. Dokumen tersebut digunakan sebagai acuan dalam pembangunan database sistem.

Observasi proses bisnis meliputi proses bisnis yang dilakukan bank sampah saat penimbangan sampah dan melaporkan hasil penimbangan setiap bulannya. Hasil dari observasi proses bisnis akan digunakan sebagai acuan pembangunan sistem supaya memenuhi kebutuhan pengguna.

\section{b) Wawancara}

Hasil wawancara adalah berupa outline wawancara yang berisi informasi terkait hambatan dan prosedur kegiatan penimbangan sampah dan pelaporan hasil penimbangan. Faktanya bahwa bank sampah mengalami kesulitan dalam melaporkan hasil penimbangan kepada LSM We Hasta dikarenakan proses yang sulit bagi mereka dan sumber daya yang tidak mencukupi. Laporan penimbangan dilakukan dengan dua pilihan cara, yaitu dengan mengirimkan melalui email atau dengan memberikan langsung ke petugas We Hasta. Permasalahan lain adalah LSM We Hasta sulit melakukan pemantauan keaktifan bank sampah dikarenakan sedikit bank sampah yang rutin melaporkan hasil penimbangan sampah. Hal ini menyebabkan data potensi bank sampah yang dimiliki We $\sim$ Hasta tidak terbaharui.

\section{B. Analisis kebutuhan}

LSM We Hasta membutuhkan rekapitulasi data secara terkomputerisasi yakni adanya sistem mengenai persebaran bank sampah di Surabaya. Selanjutnya, petugas LSM We Hasta, pengelola dan masyarakat umum termasuk pengepul dapat mengakses sistem tersebut. Penelitian ini dengan 


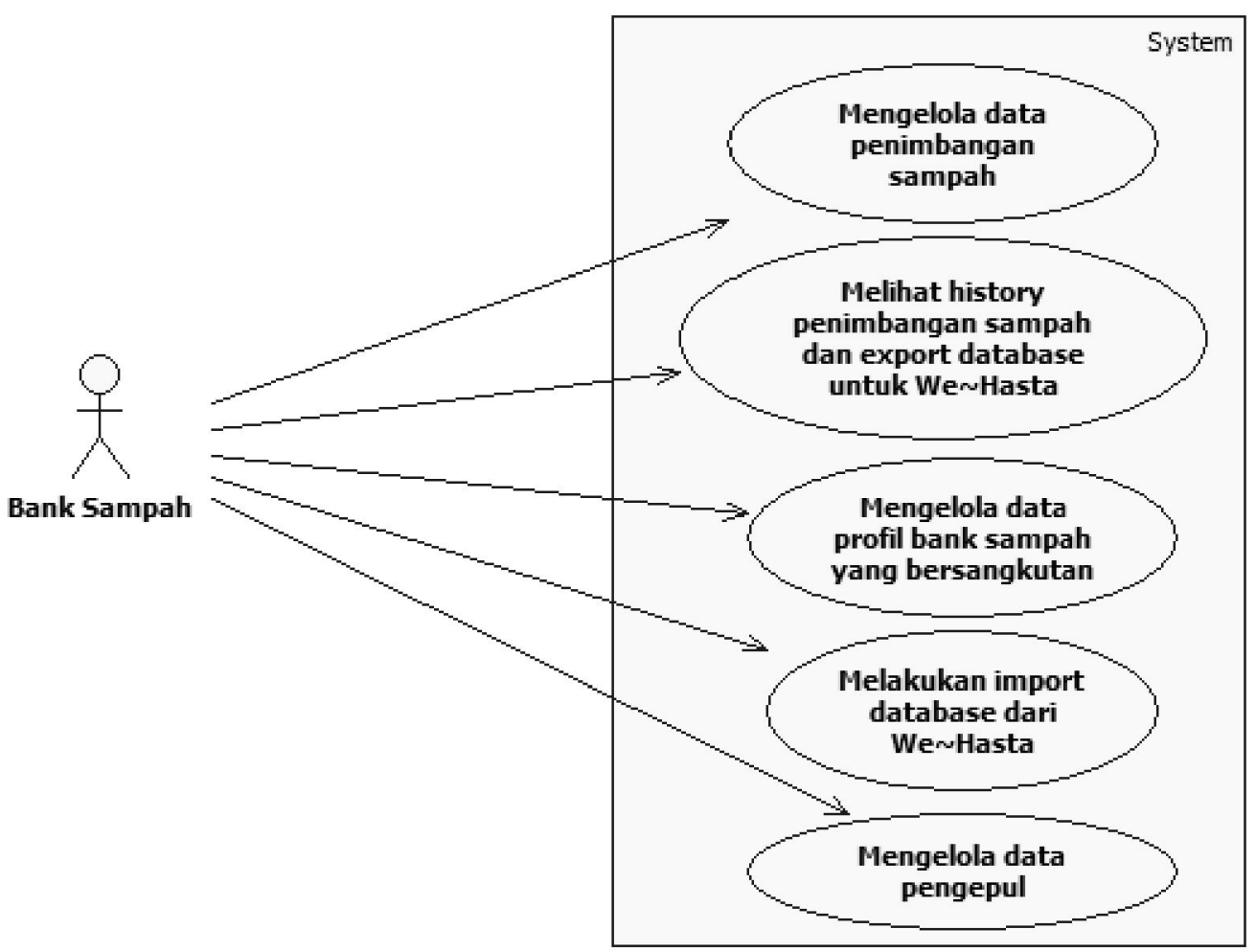

Gambar 1. Use case diagram sistem offline

dua kali pengembangan sistem. Pengembangan pertama yang dihasilkan dari hasil wawancara awal menghasilkan rancangan sistem sistem berbasis web. Namun setelah melakukan wawancara lanjutan, dihasilkan pengembangan kedua yaitu sistem dibagi menjadi dua subsistem yaitu sistem offline dan sistem online.Munculnya dua platform ini disebabkan keterbatasan sumber daya yang dialami oleh bank sampah, dikarenakan tidak semua bank sampah memiliki jangkauan internet yang cukup secara terus menerus, selain itu jika menggunakan satu platform online dalam melakukan proses bisnis bank sampah akan mengakibatkan pengeluaran yang tinggi bagi bank sampah dalam berlangganan jasa internet. Platform offline digunakan bank sampah untuk melakukan proses bisnis penimbangan sampah dan platform online digunakan We Hasta untuk mengatur data dan laporan bulanan juga digunakan oleh End user untuk melihat persebaran bank sampah di Surabaya. Use case diagram sistem offline dan sistem online dapat dilihat pada Gambar 1 dan Gambar 2.

\section{Perancangan}

a) Perancangan proses

Perancangan proses digambarkan dengan activity diagram, class diagram, dan sequence diagram. Setiap fitur memiliki activity diagram masing-masing. Berikut adalah activity diagram fitur melihat peta persebaran bank sampah yang tersaji pada Gambar 3.

Pada class diagram sistem offline terdapat delapan class view, lima class control, dan delapan class entity. Sedangkan untuk membuat sequence diagram adalah dengan mengacu pada activity diagram dan class diagram. Salah satu sequence diagram dalam sistem visualisasi data potensi bank sampah adalah import database sistem offlineyang dapat dilihat pada Gambar 4.

\section{b) Perancangan database}

Perancangan database digambarkan dengan conceptual database model (CDM). Sistem offline dan sistem online memiliki desain database yang mirip. Perbedaan desain database sistem offline dan online terdapat pada entitas bank sampah. Pada sistem online terdapat atribut email sedangkan sistem offline tidak memiliki atribut email di entitas bank sampah.

\section{Membangun prototype}

Pembangunan prototype sistem offline menggunakan bahasa pemrogaman Java berbasis desktop. Salah satu fitur yang dibangun pada sistem offline adalah mengelola data penimbangan. Antarmuka mengelola data penimbangan dapat dilihat pada Gambar 5.

Sedangkan pembangunan prototype sistem online menggunakan Bahasa pemrogaman PHP, HTML5, Javascript, dan JQuery. Salah satu fitur 


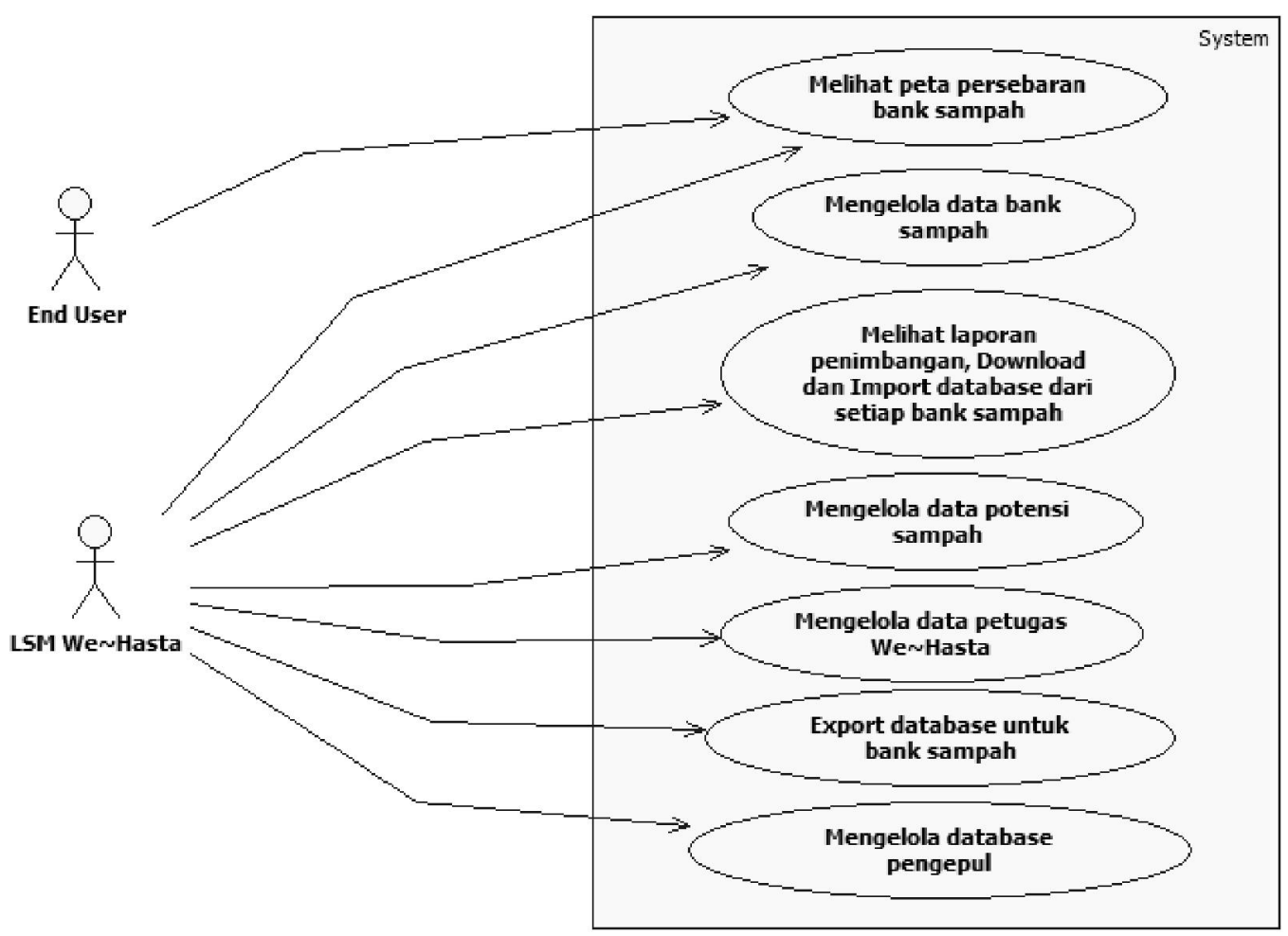

Gambar 2. Use case diagram sistem online

pada sistem online adalah fitur melihat peta persebaran bank sampah yang dapat dilihat pada Gambar 6.

\section{E. Evaluasi dengan Pengguna}

Evaluasi iterasi pertama membahas apakah sistem telah memenuhi kebutuhan pengguna. Evaluasi pertama dilakukan dalam bentuk rapat bersama pengelola bank sampah dan perwakilan We Hasta. Evaluasi pertama ini juga merupakan bahan untuk analisis pada iterasi kedua.

Hasil pada evaluasi pertama adalah bahwa pada dasarnya kebutuhan pengguna telah terpenuhi. Namun, kebanyakan pengelola bank sampah terkendala dengan fasilitas jaringan internet dan terlalu awam untuk memahami sistem berbasis web. Sebagai solusinya sistem dipisah dengan dua platform yaitu sistem offline dan sistem online. Sistem offline berbasis desktop agar lebih mudah penggunaannya bagi pengelola bank sampah. Sistem offline dapat dijalankan tanpa menggunakan koneksi internet. Sistem offline hanya digunakan oleh pengelola bank sampah. Sistem online berbasis web. Penggunaan sistem online membutuhkan jaringan koneksi internet karena berhubungan dengan API googlemap. Sistem online dapat digunakanoleh masyarakat umum untuk melihat peta persebaran bank sampah di Surabaya. Pada iterasi kedua, pengguna merasa puas dengan cara kerja sistem. Sistem dapat memenuhi kebutuhan pengguna. Sehingga tidak terdapat perubahan pada hasil perancangan dan pembangunan iterasi kedua.

\section{F. Pengembangan Skala Besar}

Pengembangan skala besar yang dimaksud adalah implementasi sistem di lingkungan bank sampah. Sistem offline dalam bentuk file executable dan sistem online dapat diakses melalui browser di komputer atau smartphone pengguna.

Pengembangan skala besar untuk sistem offline adalah sebagai berikut:

a) Source code dihimpun dalam bentuk satu file .jar

b) Melakukan instalasi aplikasi database ke PC pengelola bank sampah

c) Melakukan import database dari file sql ke aplikasi database lokal PC pengelola bank sampah

d) Menyalin file executable beserta libraryke PC pengelola bank sampah

e) Memberikan pelatihan ke pengelola bank sampah terkait cara menggunakan sistem offline.

Langkah-langkah yang dilakukan dalam pengembangan skala besar untuk sistem online adalah sebagai berikut:Pembuatan sub domain sebagai server sistem online dengan menggunakan penyedia layanan subdomain idhostinger 


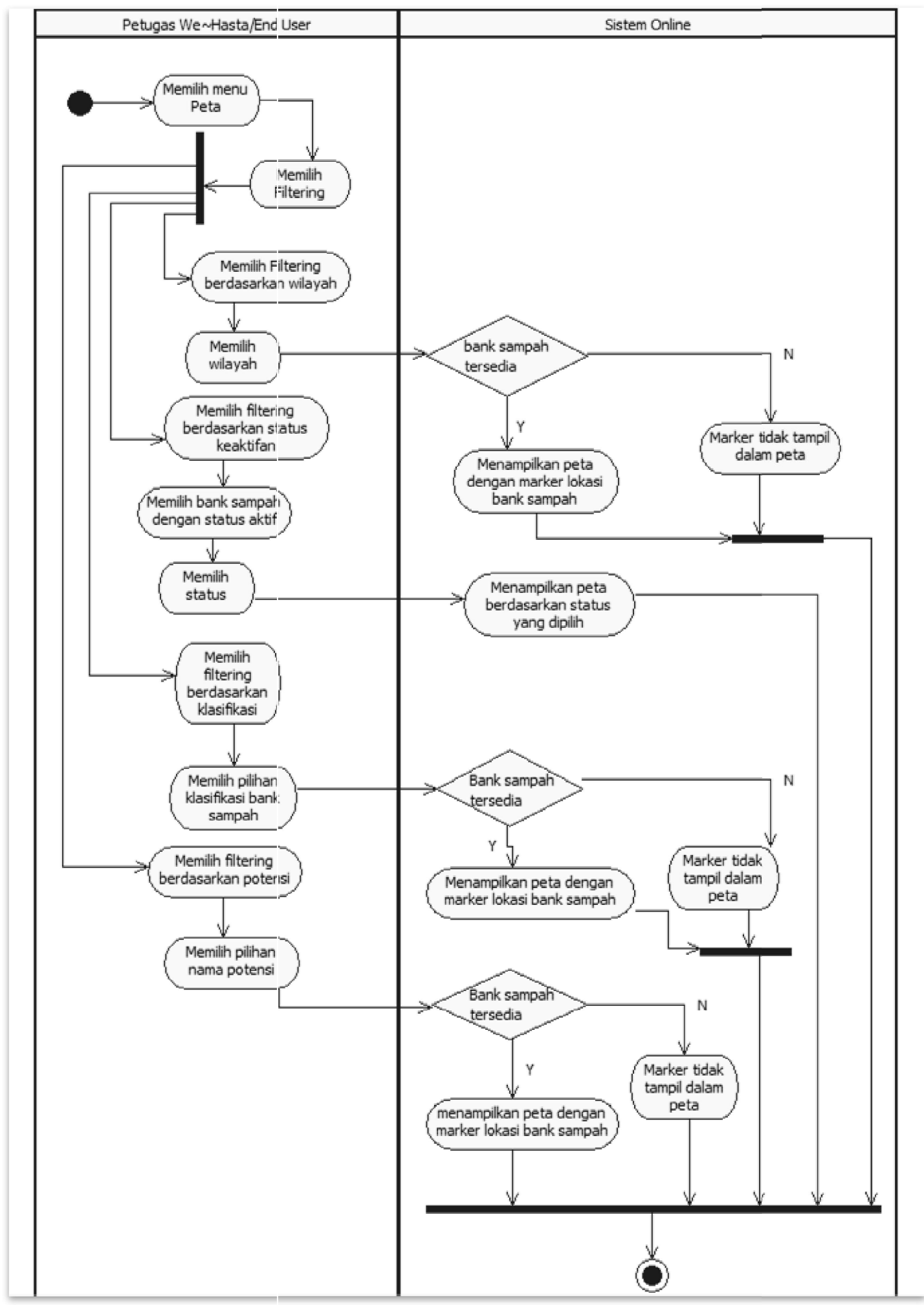

Gambar 3. Activity Diagram melihat peta persebaran bank sampah

a. Mendaftarkansubdomain"banksampahsurabay awehasta.esy.es"

b. Mengunggah direktori source code sistem online ke server

c. Membuat database MySQL di idhostinger

d. Import database sistem online ke database di idhostinger e. Memberikan pelatihan kepada petugas we hasta mengenai penggunaan sistem online untuk mengelola database bank sampah di Surabaya

f. Memberikan pelatihan kepada pengepul dan bank sampah mengenai cara melihat peta persebaran bank sampah dalam sistem online. 


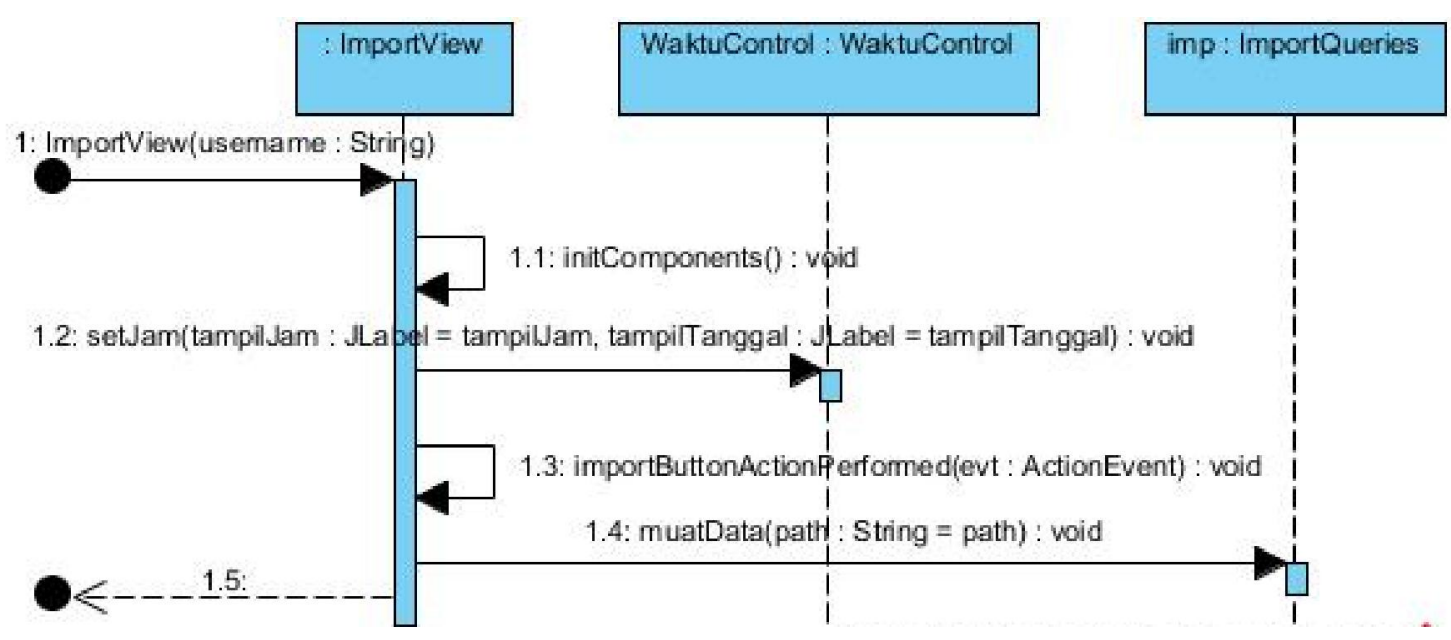

Gambar 4. Sequence diagram import database

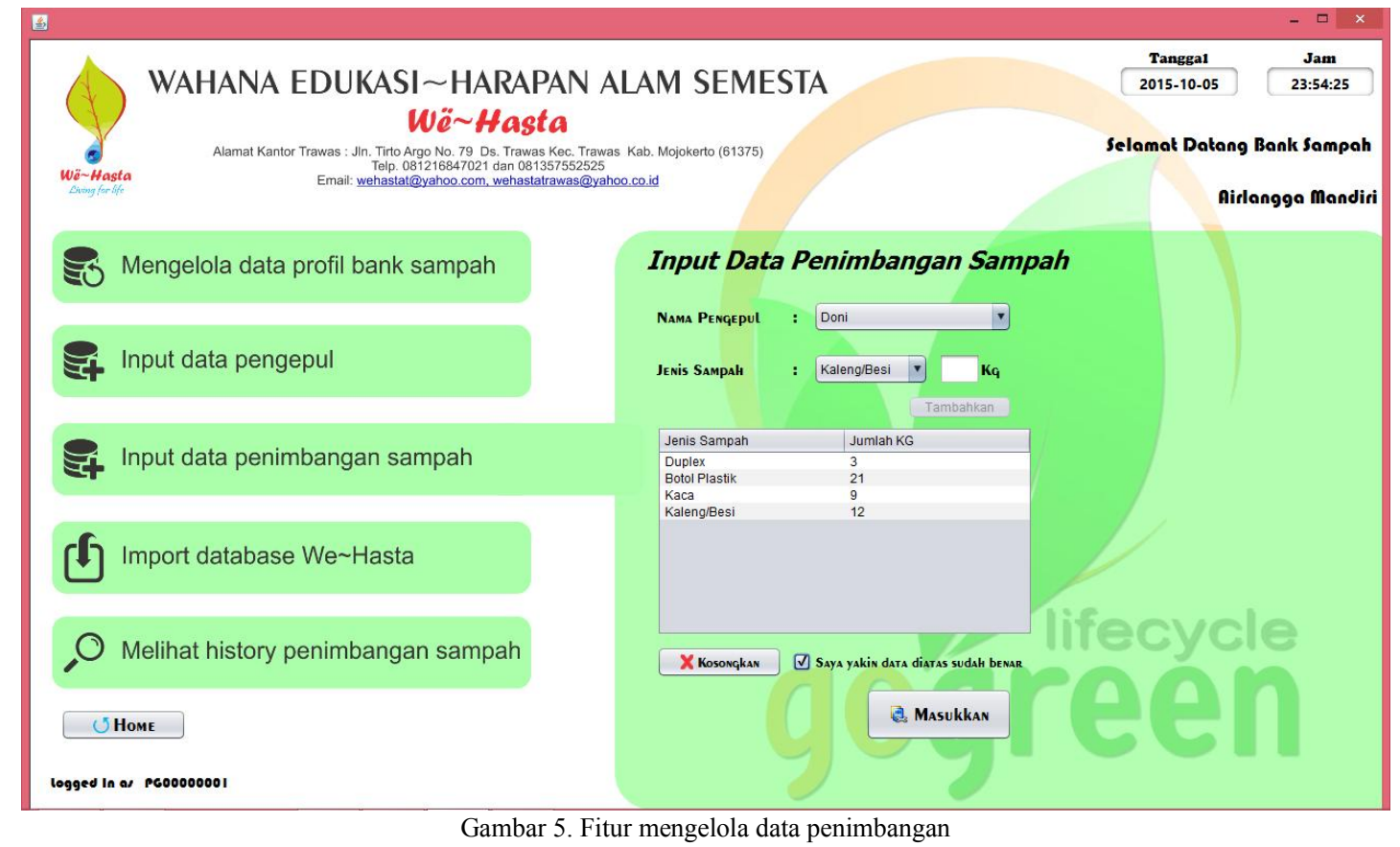

Gambar 5. Fitur mengelola data penimbangan

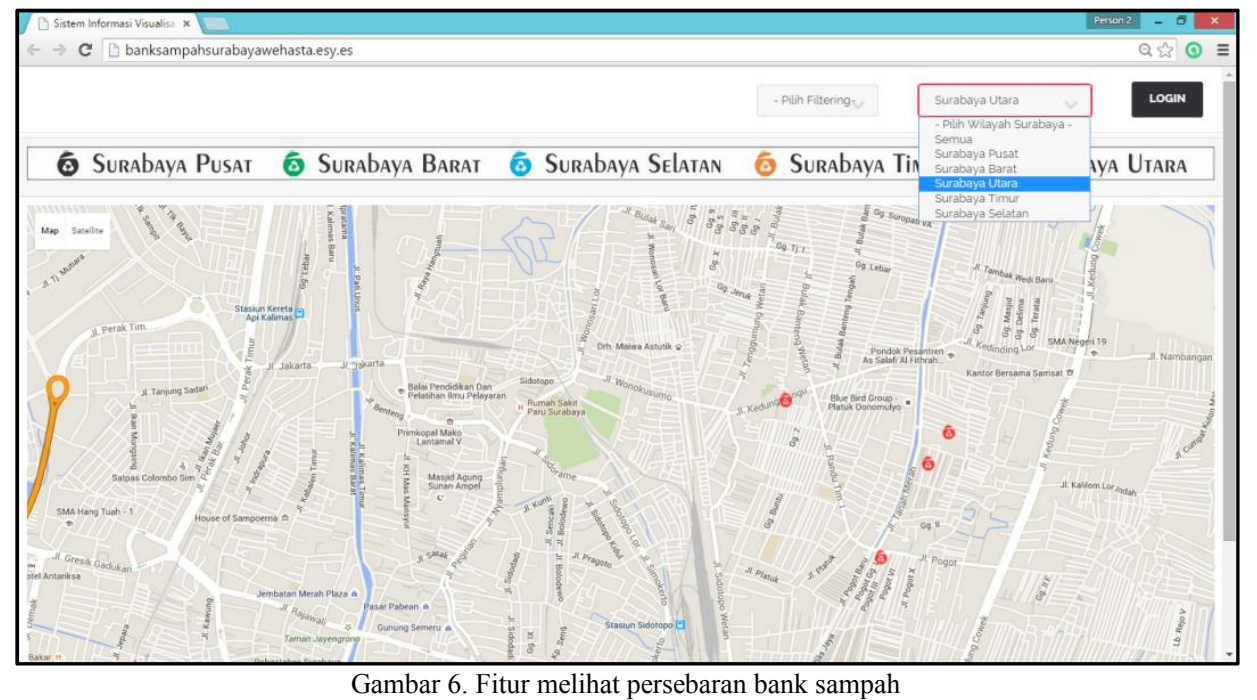

Gambar 6. Fitur melihat persebaran bank sampah 
TABEL 1. HASIL PENGISIAN KUISIONER BAGIAN 1

\begin{tabular}{|c|c|c|c|}
\hline \multirow{2}{*}{ No } & \multirow{2}{*}{ Pertanyaan } & \multicolumn{2}{|c|}{ Jawaban } \\
\hline & & Ya & Tidak \\
\hline \multicolumn{4}{|c|}{ Pengepul } \\
\hline 1 & $\begin{array}{l}\text { Fitur melihat peta lokasi bank sampah pada Sistem visualisasi data potensi bank sampahberjalan } \\
\text { dengan baik dan benar? }\end{array}$ & 5 & 0 \\
\hline 2 & $\begin{array}{l}\text { Fitur melihat peta lokasi bank sampah berdasarkan potensi sampah yang dimiliki pada Sistem } \\
\text { visualisasi data potensi bank sampah berjalan dengan baik dan benar? }\end{array}$ & 5 & 0 \\
\hline 3 & $\begin{array}{l}\text { Fitur melihat detail info kontak bank sampah pada Sistem visualisasi data potensi bank sampah } \\
\text { berjalan dengan baik dan benar? }\end{array}$ & 5 & 0 \\
\hline \multicolumn{4}{|c|}{ Bank Sampah } \\
\hline 1 & Fitur login pada Sistem visualisasi data potensi bank sampahberjalan dengan baik dan benar? & 10 & 0 \\
\hline 2 & $\begin{array}{l}\text { Fitur input data transaksi bank sampah pada Sistem visualisasi data potensi bank sampah } \\
\text { berjalan dengan baik dan benar? }\end{array}$ & 10 & 0 \\
\hline 3 & $\begin{array}{l}\text { Fitur melihat laporan keuangan bank sampah pada Sistem visualisasi data potensi bank sampah } \\
\text { berjalan dengan baik dan benar? }\end{array}$ & 10 & 0 \\
\hline 4 & $\begin{array}{l}\text { Fitur melihat perkembangan keuangan bank sampah pada Sistem visualisasi data potensi bank } \\
\text { sampah berjalan dengan baik dan benar? }\end{array}$ & 10 & 0 \\
\hline \multicolumn{4}{|c|}{ LSM We Hasta } \\
\hline 1 & Fitur login pada Sistem visualisasi data potensi bank sampahberjalan dengan baik dan benar? & 2 & 0 \\
\hline 2 & $\begin{array}{l}\text { Fitur melihat laporan keuangan seluruh bank sampah pada Sistem visualisasi data potensi bank } \\
\text { sampah berjalan dengan baik dan benar? }\end{array}$ & 2 & 0 \\
\hline 3 & $\begin{array}{l}\text { Fitur melihat peta berdasarkan status keaktifan bank sampah pada Sistem visualisasi data } \\
\text { potensi bank sampah berjalan dengan baik dan benar? }\end{array}$ & 2 & 0 \\
\hline \multicolumn{2}{|r|}{ Total Jawaban } & 61 & $\mathbf{0}$ \\
\hline \multicolumn{2}{|r|}{ Presentase } & $100 \%$ & $0 \%$ \\
\hline
\end{tabular}

TABEL 2. HASIL PENGISIAN KUISIONER BAGIAN 2

\begin{tabular}{|c|c|c|c|c|c|c|}
\hline \multirow{2}{*}{\multicolumn{2}{|c|}{ Pernyataan }} & \multirow{3}{*}{$\begin{array}{l}\text { Pengguna } \\
\text { End user }\end{array}$} & \multicolumn{4}{|c|}{ Persentase jumlah jawaban } \\
\hline & & & \multirow{2}{*}{$\begin{array}{c}\begin{array}{c}\text { Sangat } \\
\text { setuju }\end{array} \\
40 \%\end{array}$} & \multirow{2}{*}{$\begin{array}{c}\text { Setuju } \\
60 \%\end{array}$} & \multirow{2}{*}{$\begin{array}{c}\text { Tidak } \\
\text { Setuju }\end{array}$} & \multirow{2}{*}{$\begin{array}{r}\text { Sanga } \\
\text { Tidak } \\
\text { Setuju } \\
0 \%\end{array}$} \\
\hline $\begin{array}{llll}\text { Saya } & \text { merasa } & \text { penggunaan } & \text { Sistem }\end{array}$ & \multirow{3}{*}{ P1 } & & & & & \\
\hline visualisasi data potensi bank sampah & & Bank Sampah & $30 \%$ & $70 \%$ & $0 \%$ & $0 \%$ \\
\hline bermanfaat dalam pekerjaan & & LSM We Hasta & $50 \%$ & $50 \%$ & $0 \%$ & $0 \%$ \\
\hline \multirow{3}{*}{$\begin{array}{l}\text { Saya merasa penggunaan Sistem } \\
\text { visualisasi data mampu meningkatkan } \\
\text { penyelesaian tugas lebih cepat }\end{array}$} & \multirow{3}{*}{$\mathbf{P 2}$} & End user & $60 \%$ & $40 \%$ & $0 \%$ & $0 \%$ \\
\hline & & Bank Sampah & $20 \%$ & $80 \%$ & $0 \%$ & $0 \%$ \\
\hline & & LSM We Hasta & $0 \%$ & $100 \%$ & $0 \%$ & $0 \%$ \\
\hline \multirow{3}{*}{$\begin{array}{l}\text { Saya mampu meningkatkan } \\
\text { produktivitas jika menggunakan Sistem } \\
\text { visualisasi data potensi bank sampah }\end{array}$} & \multirow{3}{*}{ P3 } & End user & $40 \%$ & $60 \%$ & $0 \%$ & $0 \%$ \\
\hline & & Bank Sampah & $70 \%$ & $30 \%$ & $0 \%$ & $0 \%$ \\
\hline & & LSM We Hasta & $50 \%$ & $50 \%$ & $0 \%$ & $0 \%$ \\
\hline \multirow{3}{*}{$\begin{array}{l}\text { Saya memiliki sumberdaya (waktu, dana, } \\
\text { dsb) yang cukup untuk menggunakan } \\
\text { Sistem visualisasi data potensi bank } \\
\text { sampah }\end{array}$} & \multirow{3}{*}{ P4 } & End user & $20 \%$ & $20 \%$ & $40 \%$ & $20 \%$ \\
\hline & & Bank Sampah & $10 \%$ & $40 \%$ & $50 \%$ & $0 \%$ \\
\hline & & LSM We Hasta & $100 \%$ & $0 \%$ & $0 \%$ & $0 \%$ \\
\hline \multirow{3}{*}{$\begin{array}{l}\text { Saya memiliki pengetahuan yang cukup } \\
\text { untuk bisa menggunakan Sistem } \\
\text { visualisasi data potensi bank sampah }\end{array}$} & \multirow{3}{*}{ P5 } & End user & $0 \%$ & $80 \%$ & $20 \%$ & $0 \%$ \\
\hline & & Bank Sampah & $10 \%$ & $80 \%$ & $10 \%$ & $0 \%$ \\
\hline & & LSM We Hasta & $50 \%$ & $50 \%$ & $0 \%$ & $0 \%$ \\
\hline \multirow{3}{*}{$\begin{array}{l}\text { Terdapat orang yang membantu jika } \\
\text { saya mengalami kesulitan dalam } \\
\text { menggunakan Sistem visualisasi data } \\
\text { potensi bank sampah. }\end{array}$} & \multirow{3}{*}{ P6 } & End user & $0 \%$ & $40 \%$ & $60 \%$ & $0 \%$ \\
\hline & & Bank Sampah & $20 \%$ & $80 \%$ & $0 \%$ & $0 \%$ \\
\hline & & LSM We Hasta & $50 \%$ & $50 \%$ & $0 \%$ & $0 \%$ \\
\hline \multirow{3}{*}{$\begin{array}{l}\text { Saya puas terhadap Sistem visualisasi } \\
\text { data potensi bank sampah }\end{array}$} & \multirow{3}{*}{ P7 } & End user & $40 \%$ & $60 \%$ & $0 \%$ & $0 \%$ \\
\hline & & Bank Sampah & $70 \%$ & $30 \%$ & $0 \%$ & $0 \%$ \\
\hline & & LSM We Hasta & $100 \%$ & $0 \%$ & $0 \%$ & $0 \%$ \\
\hline \multirow{3}{*}{$\begin{array}{l}\text { Saya puas menggunakan Sistem } \\
\text { visualisasi data potensi bank sampah }\end{array}$} & \multirow{3}{*}{ P8 } & End user & $20 \%$ & $80 \%$ & $0 \%$ & $0 \%$ \\
\hline & & Bank Sampah & $60 \%$ & $40 \%$ & $0 \%$ & $0 \%$ \\
\hline & & LSM We Hasta & $50 \%$ & $50 \%$ & $0 \%$ & $0 \%$ \\
\hline \multirow{3}{*}{$\begin{array}{l}\text { Informasi yang ditampilkan pada Sistem } \\
\text { visualisasi data potensi bank sampah } \\
\text { terbaharui secara real time }\end{array}$} & \multirow{3}{*}{ P9 } & End user & $20 \%$ & $80 \%$ & $0 \%$ & $0 \%$ \\
\hline & & Bank Sampah & $40 \%$ & $60 \%$ & $0 \%$ & $0 \%$ \\
\hline & & LSM We Hasta & $50 \%$ & $50 \%$ & $0 \%$ & $0 \%$ \\
\hline \multirow{3}{*}{$\begin{array}{l}\text { Sistem visualisasi data potensi bank } \\
\text { sampah mudah dimengerti }\end{array}$} & \multirow{3}{*}{$\mathbf{P} 10 \%$} & End user & $40 \%$ & $60 \%$ & $0 \%$ & $0 \%$ \\
\hline & & Bank Sampah & $60 \%$ & $40 \%$ & $0 \%$ & $0 \%$ \\
\hline & & LSM We Hasta & $100 \%$ & $0 \%$ & $0 \%$ & $0 \%$ \\
\hline
\end{tabular}

\section{G. Evaluasi Sistem}

Evaluasi sistem menggunakan kuesioner dengan perwakilan LSM We Hasta, pengelola bank sampah, dan pengepul. Evaluasi sistem dilakukan setelah melakukan simulasi penggunaan sistem dengan 2 perwakilan We Hasta, 10 pengelola bank sampah, 2 pengepul, dan 3 masyarakat umum.

Secara ringkas, jawaban responden berdasarkan hasil kuisioner yang terlampir di 


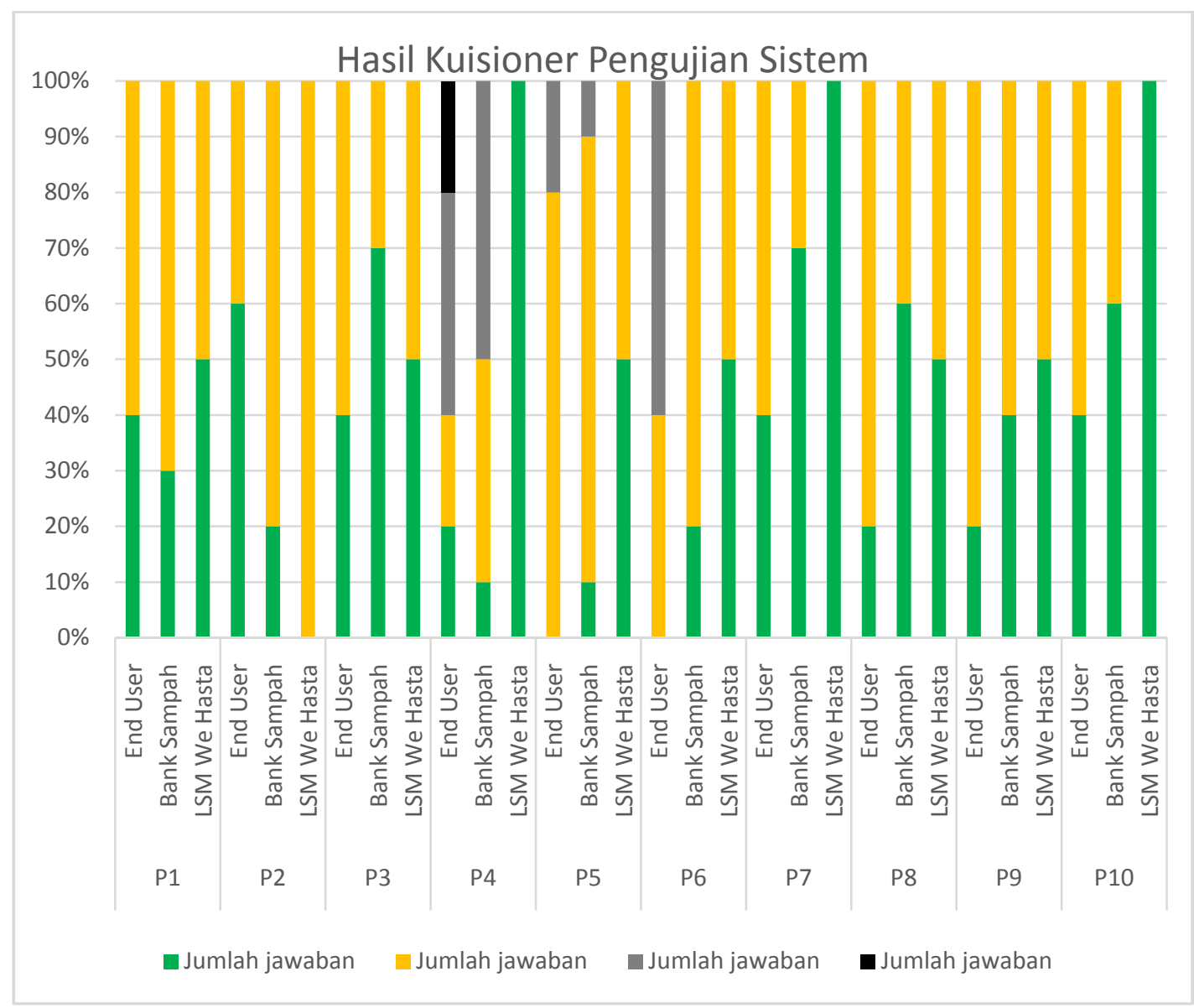

GAMBAR 7 GRAFIK HASIL KUISIONER BAGIAN 2

Tabel 1, Tabel 2 dan Gambar 7adalah sebagai berikut:

a) Seluruh responden menyatakan bahwa fitur utama sistem berjalan sesuai kebutuhan.

b) End user, bank sampah, dan LSM We Hasta menyatakan setuju bahwa sistem visualisasi data potensi bank sampah bermanfaat dalam pekerjaan, mempercepat kinerja dan meningkatkan produktivitas.

c) Terjadi ketimpangan di sisi sumber daya, pada saat ini pihak End user dan bank sampah memiliki sumber daya yang kecil untuk menjalankan sistem visualisasi datapotensi bank sampah, sedangkan LSM We Hasta memiliki sumber daya yang cukup untuk menjalankannya.

\section{KESIMPULAN}

Perancangan dan pembangunan sistem informasi geografis menghasilkan fitur untuk visualisasi data bank sampah di Surabaya yang terbagi menjadi 2 sistem, yaitu sistem offline dan sistem online. Fitur di dalam sistem offline terdiri dari mengelola data bank sampah, melihat history penimbangan sampah dan export database untuk We Hasta, mengelola data profil bank sampah, melakukan import database dari We Hasta, mengelola data pengepul. Fitur dalam sistem online adalah melihat peta persebaran bank sampah, mengelola data bank sampah, melihat laporan penimbangan, download dan import database dari setiap bank sampah, mengelola data potensi sampah, mengelola data petugas We Hasta, export database untuk bank sampah, mengelola database pengepul.

Evaluasi keberhasilan dari sistem informasi geografis untuk visualisasi data potensi bank sampah menghasilkan tanggapan positif dari pengguna sistem bahwa secara keseluruhan sistem sudah berjalan dengan baik dan benar. Pengguna merasa puas atas kinerja sistem visualisasi data karena dapat membantu kinerja menjadi lebih cepat dan meningkatkan produktivitas. Informasi yang ditampilkan pada sistem visualisasi data juga sesuai kebutuhan pengguna dan data selalu diperbaharui secara real time.

Pengumpulan data nasabah setiap bank sampah. Data nasabah dapat terdiri dari alamat beserta latitudelongitude rumah nasabah. Data latitudelongitude nasabah dapat digunakan untuk mengetahui daerah jangkauan setiap bank sampah pada peta persebaran bank sampah di sistem online. Penambahan data latitudelongitude perbatasan setiap kecamatan 
sehingga dapat digunakan untuk perbedaan warna pada setiap kecamatan pada peta persebaran bank sampah di sistem online. Sistem online visualisasi data potensi bank sampah selanjutnya diharapkan dapat mengirim email kepada bank sampah secara otomatis melalui sistem

\section{DAFTAR PUSTAKA}

Fitria, R. (2015). Perancangan Sistem Informasi Pengelolaan Bank Sampah Berbasis Web dengan Fitur Mobile. Skripsi, Universitas Andalas, Sistem Informasi.

Hai, S., \& Dai, T. (2013). Online Map Application Development Using Google Maps API, SQL Database and ASP.NET. International Journal of Information and Communication Technology Research , 3 (3), 102-110.

Keim, D. A. (2002). Information Visualization and Visual Data Mining. IEEE Transactions on Visualization and Computer Graphics , 8 (1), 100-107.
Maziya, F. B. (2014). Potensi Emisi Gas Rumah Kaca dari Pengelolaan Sampah Domestik Kecamatan Genteng Surabaya Pusat. Skripsi, Institut Teknologi Sepuluh Nopember, Teknik Lingkungan.

Noviandi, B. M., Destiani, D., \& Partono. (2012). Perancangan Sistem Informasi Inventori Barang Di Bank Sampah Garut. Jurnal Algoritma , 9 (1), 1-13.

Reveiu, A., \& Dardala, M. (2011). Techniques For Statistical Data Visualization in Geographical Information System. Informatica Economica , 15 (3), 72-79.

Surabaya, B. P. (2014, Desember 23). Badan Pusat Statistik Kota Surabaya. Retrieved Oktober 28, 2015, from Jumlah Penduduk Menurut Jumlah Rumah Tangga: http://surabayakota.bps.go.id/

Utami, E. (2013). Buku Panduan Sistem Bank Sampah dan 10 Kisah Sukses. Jakarta: Yayasan Unilever Indonesia. 